ENTREPRENEURSHIP AND SUSTAINABILITY ISSUES

ISSN 2345-0282 (online) http://jssidoi.org/jesi/ 2021 Volume 9 Number 2 (December)

http://doi.org/10.9770/jesi.2021.9.2(35)
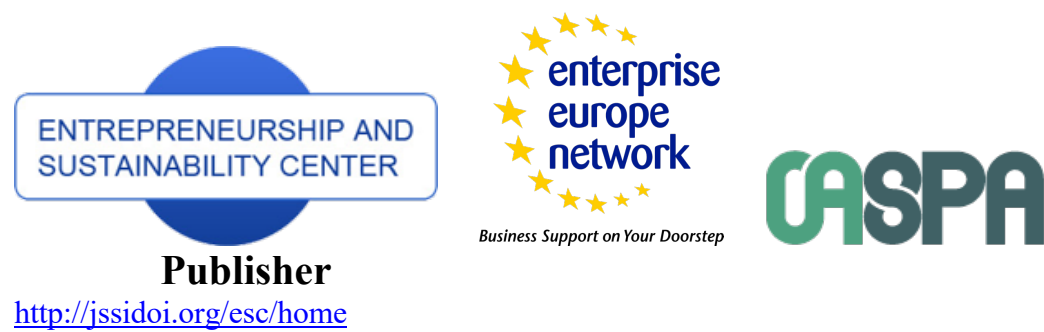

http://jssidoi.org/esc/home

\title{
RELATIONSHIPS BETWEEN ROAD TRANSPORT INFRASTRUCTURE AND TOURISM SPENDING: A DEVELOPMENT APPROACH IN EUROPEAN OECD COUNTRIES*
}

\author{
Viera Ivankova ${ }^{1}$, Beata Gavurova ${ }^{2}$, Radovan Bacik ${ }^{3}$, Martin Rigelsky ${ }^{4}$ \\ ${ }^{1,2}$ Technical University of Košice, Faculty of Mining, Ecology, Process Control and Geotechnologies, Letná 9, 04200 \\ Košice, Slovakia \\ 3,4 University of Prešov, Konštantínova 16, Faculty of Management, Department of Marketing and International Trade, \\ 08001 Prešov, Slovakia
}

E-mails: ${ }^{1}$ viera.ivankova@tuke.sk; ${ }^{2}$ beata.gavurova@tuke.sk ; ${ }^{3}$ radovan.bacik@unipo.sk ; ${ }^{4}$ martin.rigelsky@unipo.sk

Received 15 September 2021; accepted 25 November 2021; published 30 December 2021

\begin{abstract}
Road transport infrastructure is an attribute whose importance is increasingly emphasized in the context of a circular and sustainable economy. However, the link between this attribute and tourism spending has not been sufficiently examined. Therefore, with an emphasis on the level of development of European countries included in the Organisation for Economic Co-operation and Development (OECD), the research objective of this study was to assess the links between selected indicators of road transport and tourism spending. The analytical processing included economic data provided by international organizations and collected for the period 2010-201. Specifically, Human Development Index (HDI), Global Innovation Index (GII), Density of road (DENSITY), Share of urban roads (URBAN), Road infrastructure investment (INVEST), Business tourism spending (BTS), Leisure tourism spending (LTS), Domestic tourism spending (DTS), Foreign visitors spending (VEFS). The research sample consisted of European OECD countries ( $\mathrm{n}=26)$. Cluster analysis (Partition Around Medoids) divided selected countries based on HDI and GII into two clusters (less developed and more developed countries). The use of descriptive analysis together with analysis of differences (Mann - Whitney test) showed significant differences between these two clusters in most indicators (DENSITY, INVEST, BTS, LTS, DTS), while their higher values were measured in more developed countries with the exception of INVEST. Differences between clusters of countries were also revealed by correlation analysis (Spearman's $\rho$ ). In countries with a lower level of development, a panel regression analysis confirmed significant positive associations between DENSITY and tourism spending (BTS, LTS, VEFS). The results indicated that the development of countries played an important role in evaluating the links examined in this study. In less developed countries, progress in the development of road infrastructure could be associated with increased tourism spending.
\end{abstract}

Keywords: road, transport infrastructure, tourism, spending, sustainability, OECD countries, development, panel regression analysis

\footnotetext{
* This paper is one of the partial outputs under the scientific research grant VEGA 1/0694/20 - Relational marketing research - perception of e-commerce aspects and its impact on purchasing behaviour and consumer preferences and VEGA 1/0609/19 - Research on the development of electronic and mobile commerce in the aspect of the impact of modern technologies and mobile communication platforms on consumer behaviour and consumer preferences. This research was supported by the Scientific Grant Agency of the Ministry of Education, Science, Research, and Sport of the Slovak Republic and the Slovak Academy Sciences as part of the research project VEGA 1/0797/20: Quantification of Environmental Burden Impacts of the Slovak Regions on Health, Social and Economic System of the Slovak Republic.
} 


\section{ENTREPRENEURSHIP AND SUSTAINABILITY ISSUES}

ISSN 2345-0282 (online) http://jssidoi.org/jesi/ 2021 Volume 9 Number 2 (December)

http://doi.org/10.9770/jesi.2021.9.2(35)

Reference to this paper should be made as follows: Ivankova, V., Gavurova, B., Bacik, R., Rigelsky, M. 2021. Relationships between road transport infrastructure and tourism spending: A development approach in European OECD countries. Entrepreneurship and Sustainability Issues, 9(2), 535-551. http://doi.org/10.9770/jesi.2021.9.2(35)

JEL Classifications: L83, L90, O11, Z32

\section{Introduction}

Tourism can be considered a very important sector of the economy of many countries (Dogru \& Bulut 2018, Uslu et al. 2020). Evidence of this statement is the significant contribution of tourism to gross domestic product (GDP) in countries (World Travel \& Tourism Council [WTTC] 2020). This underlines the need to constantly examine this sector from different perspectives in order to identify significant factors with the potential for tourism development. One of these factors may be transport infrastructure, specifically road transport infrastructure (Vochozka \& Sheng 2016, Lăzăroiu et al. 2020). There is no doubt that tourism and transport infrastructure are economically beneficial (Albaladejo et al. 2021, Chen et al. 2021, Haller et al. 2020, Nenavath 2021), and there is a presumption that they are interconnected. Li et al. (2015) emphasized that transport infrastructure always plays an important role in the development of tourism. According to the authors, the behaviour of tourism visitors when choosing a destination is characterized by a multinomial logit choice model based on the utility of destinations, which largely depends on the accessibility of destinations ( $\mathrm{Li}$ et al. 2015, Liska 2016). This supports the willingness of policy makers to improve road transport infrastructure, as countries need to grow in terms of transport infrastructure and tourism in order to make economic gains (Horak et al. 2020). The above-mentioned facts were the greatest motivation for conducting the presented research, which focused on the links between selected indicators of road transport and tourism spending with an emphasis on the development approach in European OECD countries. For these reasons, this paper differs from other studies that analyse the marketing (Civelek et al. 2020) and innovative activities of various businesses in the tourism sector (Civelek et al. 2021, Ključnikov et al. 2021), and investigate the economic development of touristic locations (Ključnikov et al. 2020a, Ključnikov et al. 2020b) of some European countries. The structure of the study is as follows: the introduction section describes the main focus of the study. The theoretical background section provides key information on the issue in order to find out where the scientific knowledge is. The methodological section contains a description of the data as well as the methods used in the analytical process. The obtained results were the basis for discussion in the fourth section. The section of conclusions provides a brief summary of the most important findings from the study and a formulation of recommendations.

\section{Theoretical background}

As indicated above, transport infrastructure and tourism are two areas of economic life in countries that play an irreplaceable role in developing policies and plans aimed at sustainable development (Vochozka et al. 2016). These areas offer opportunities for socially responsible improvements that, in addition to generating economic benefits, also respect the environment and quality of life (Belas et al. 2018, 2020a, 2020b). Economic, social, environmental, innovative and cultural factors are vital for the development of sustainable tourism in countries and need to focus on stimulating and ensuring the positive effect of tourism infrastructure on concrete beneficial outcomes (Mamirkulova et al. 2020). Zhang J. and Zhang Y. (2021) investigated the dynamic link between tourism and transport infrastructure and confirmed the bidirectional Granger causality between highway and tourism. In addition, they revealed the fact that tourism and transport infrastructure have a synergy effect on income inequality. Costea et al. (2017) considered transport infrastructure to be a key determinant of competitiveness of tourism. According to these authors, the availability of a secure and fast transport network to the most important tourist centres of a country is vital. No tourist resource, no matter how important, can be effectively implemented without transport infrastructure. Thus, the absence or an insufficient development of 


\section{ENTREPRENEURSHIP AND SUSTAINABILITY ISSUES}

ISSN 2345-0282 (online) http://jssidoi.org/jesi/ 2021 Volume 9 Number 2 (December) http://doi.org/10.9770/jesi.2021.9.2(35)

infrastructure can be a major factor of the lack of development of tourism activities (Costea et al. 2017). This is in line with the findings of Khadaroo and Seetanah (2008), who stated that transport infrastructure is a significant determinant of tourism inflows into a destination. In their other study, they revealed that tourists from Europe/America and Asia are particularly sensitive to transport infrastructure (Khadaroo \& Seetanah 2007). Based on their results, transport infrastructure, non-transport infrastructure, but also income of tourists, distance, and relative prices are important elements in the equation of demand in tourism. At this point, the inflows and demand in tourism can be expressed by tourists' spending. All these findings support the importance of investigating the link between transport infrastructure and tourism at an international level and justify the presented research.

With the growing research interest in tourism and transport infrastructure, it is possible to identify different perspectives on the examination of these two areas. Nguyen (2021) examined the impact of investment in tourism infrastructure development on attracting international visitors. Using the potential accessibility approach, Michniak et al. (2014) investigated the impact of investments in road infrastructure on tourism development in terms of intensification of stays. Jou et al. (2012) focused on the influence of new road infrastructure on tourism behaviour. Wendt et al. (2021) examined the correlations between the development of the transport network and the increase in tourist traffic, and their results show that transport infrastructure plays a critical role in ensuring the connections of border regions. Kanwal et al. (2020) examined the relationship between perceived impact of road and transport infrastructure development and local community support for tourism through perceived environmental impact, perceived tourism benefits, and perceived community satisfaction. On the other hand, there is still a lack of knowledge on the link between road transport infrastructure and tourism demand represented by visitors' spending. Stehel and Vochozka (2016) examined economic added value in the transport sector. In connection with economic added value, Vochozka and Machová (2018) further examined the value generators of transport companies in the Czech Republic. Majerova and Fernandes (2020) examined brand loyalty as a future pillar of resuscitation of brand value in tourism and identified relevant sources of brand value relevant to brands characterized by loyalty.

The issue under investigation provides many indicators as appropriate measures of tourism development, but tourism spending is a crucial indicator that provides high economic value (Brida \& Scuderi 2013, Garcia-Sanchez et al. 2013, Usmani et al. 2021). Compared to tourist arrivals, tourism spending captures not only the tourist attractiveness of a country, but also the behaviour of tourists in terms of their consumption of goods and services in a visited country as well as the economic effect (Fredman 2008, Wang \& Davidson 2010). In this context, tourism spending is very closely linked to tourism participation, and the opposite is also true (Gavurova et al. 2020, Wu et al. 2013, Yang et al. 2021). At the same time, in the issue of tourism spending, it is necessary to take into account the purpose of traveling and spending money in a country. In this context, the main purposes include leisure activities and business activities of tourists (Uyen 2019). Leisure tourism covers purposes, in which recreation, relaxation, exploring new places and cultures, and hobbies play a dominant role (David-Negre et al. 2018, Venkatesh 2006). Business tourism covers work-related purposes, the core of which are meetings and events of a commercial, educational and governmental nature (Dragicevic et al. 2012, Nicula \& Elena 2014). In addition to the above-mentioned, there are many other criteria for classifying tourism spending that should be taken into account in research in order to provide a deeper insight into the issue. For example, the place of residence may offer a closer look at both domestic and foreign tourists.

The facts presented in the previous paragraphs encourage the examination of the links between transport infrastructure and tourism demand, while this study took into account specific types of transport infrastructure, i.e., road transport infrastructure. In addition, tourism demand in this study was expressed by tourists' spending, which were classified in terms of purpose (business and leisure) and in terms of borders (domestic and foreign). This provided a deeper insight into the issue. 


\section{ENTREPRENEURSHIP AND SUSTAINABILITY ISSUES}

ISSN 2345-0282 (online) http://jssidoi.org/jesi/ 2021 Volume 9 Number 2 (December)

http://doi.org/10.9770/jesi.2021.9.2(35)

\section{Research objective and methodology}

With an emphasis on the level of development of European OECD countries, the research objective of this study was to assess the links between selected indicators of road transport and tourism spending using bivariate analysis of effects. This objective was met in three analytical steps:

- Dividing countries into clusters based on their innovation potential and development.

- Providing basic statistical information on data through descriptive analysis.

- Assessment of bivariate associations using correlation and regression analyses.

The analyses covered selected OECD countries with a geographical location in the European area. Thus, 26 countries were included in the research: Austria (AUS), Belgium (BEL), Czech Republic (CZE), Denmark (DEU), Estonia (EST), Finland (FIN), France (FRA), Germany (DEU), Greece (GRC), Hungary (HUN), Iceland (ICL), Ireland (IRL), Italy (ITA), Latvia (LVA), Lithuania (LTU), Luxembourg (LUX), Netherlands (NDL), Norway (NOR), Poland (POL), Portugal (POR), Slovak Republic (SVK), Slovenia (SVN), Spain (ESP), Sweden (SWE), Switzerland (CHE), United Kingdom (GBR). The observed period in these countries was 2010 to 2018 , while the innovation index for these countries was collected from the reports from 2011 to 2019, as they contained data with a one-year lag.

The whole analytical process included data obtained from the following databases:

- Human Development Reports (2021) for the Human Development Index (HDI): A composite index measuring average achievement in three basic dimensions of human development - a long and healthy life, knowledge and a decent standard of living (measured in a score from 0 to 1; the higher the score, the more positive the evaluation).

- Cornell University, INSEAD and WIPO (2021) for the Global Innovation Index (GII): It ranks the innovation ecosystem performance of economies around the globe each year while highlighting innovation strengths and weaknesses and particular gaps in innovation metrics (measured in a score from 0 to 100; the higher the score, the more positive the evaluation).

- Organisation for Economic Co-operation and Development database (OECD 2021): (i) Density of road $\mathrm{km}$ per one hundred square km (DENSITY); (ii) Share of urban roads in total road network (URBAN); (iii) Road infrastructure investment per gross domestic product (INVEST).

- World Travel \& Tourism Council database (WTTC 2020): (i) Business tourism spending (BTS) spending of domestic residents and foreign visitors during business trips in a country (USD per capita); (ii) Leisure tourism spending (LTS) - spending of domestic residents and foreign visitors on leisure purposes in a country (USD per capita); (iii) Domestic tourism spending (DTS) - spending of domestic residents on business and leisure purposes in a country (USD per capita); (iv) Foreign visitors spending (VEFS) - spending of foreign visitors on business and leisure purposes in a country, including transport spending, but excluding international spending on education (USD per capita).

The data on tourism spending were mathematically adjusted, as the WTTC database provided gross values per country in billions of dollars:

$$
T S_{i}=\frac{\frac{T S_{i} \times 1,000,000,000}{P O P U L A T I O N_{i}}}{\frac{P P P_{i}}{100}}
$$

The whole analytical process was divided into two integral parts. The first part was devoted to cluster analysis, the purpose of which was to divide countries into homogenous clusters based on their HDI and GII. Prior to this analysis, the silhouette method was used to estimate the optimal number of clusters. The cluster analysis was based on Partitioning Around Medoids (PAM) method and Manhattan distance (Kassambara 2017). At this point, 
it should be noted that the clusters of countries identified by the cluster analysis were applied in further analyses of this research. Thus, the interpretations of their results were formulated in terms of a cluster of less developed countries and a cluster of more developed countries. In the first part of the whole analytical process, a descriptive analysis was also used to point out the statistical characteristics of the data in terms of central tendency measures (mean, median). This analysis also included an assessment of the differences in selected indicators between individual clusters. The nonparametric Mann-Whitney $U$ test was used for this purpose. The second part of the whole analytical process consisted of correlation analysis and regression analysis. The correlation analysis was performed using a nonparametric method, i.e., Spearman's $\rho$. The regression analysis was performed in two steps: (i) first, the assumptions were verified to select a suitable model (fixed effects / random effects), (ii) second, panel regression analysis was applied. F tests (FT ID, FT Time) verified the significance of effects in the internal data structure with respect to its country dimension (ID) and its time dimension (Time). This step justified the application of panel models. The Hausman test (HT) was used to decide on the choice of a regression model with fixed effects or a regression model with random effects (Wooldridge 2010). The above-mentioned analytical procedures were performed using the R programming language - version: 4.1.1, nickname: Kick Things (R Core Team 2021) and IDE PyCharm (JetBrains s.r.o., Prague, Czech Republic).

\section{Results and discussion}

This section presents the main results of the analyses described in the methodology. At the beginning of this section, the cluster analysis was carried out, and the essence of this analysis was the division of countries into homogenous clusters in terms of their level of development represented by HDI and GII indicators. For this purpose, the data (GII and HDI) collected for each country were first averaged over the observed period. Subsequently, the averaged values were standardized in the range of 0 to 1 , with 0 representing the lowest average score and 1 the highest average score.

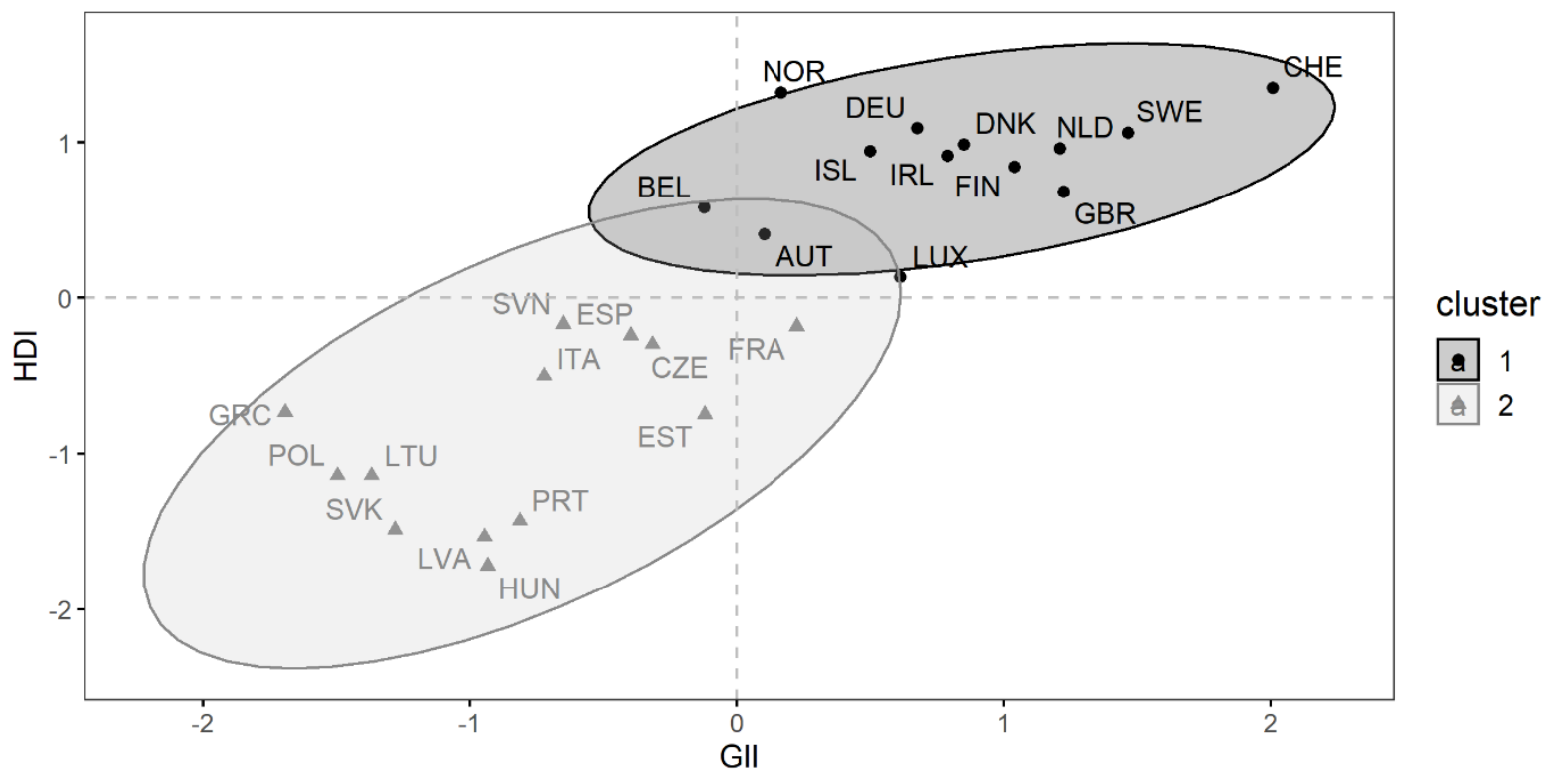

Figure 1. Cluster map - GII \& HDI

Source: own elaboration 
In terms of cluster analysis, the first step was focused on determining the optimal number of clusters using the silhouette method. Two clusters of countries were estimated for the cluster analysis using the PAM method based on the Manhattan distance. Figure 1 shows a cluster map, in which the first cluster included countries with a higher level of development represented by HDI and GII and the second cluster covered countries with a lower level of development. Accordingly, the most developed countries were Switzerland, Sweden and the Netherlands. On the other hand, less developed countries could be considered as countries with great potential to improve their development. The convergence theory indicates faster progress in weaker countries compared to stronger countries, and in this way weaker countries can more easily get closer to stronger countries. A well-designed policy can avoid the risk of middle income and many other economic imperfections that have affected several countries with higher levels of development. A similar idea was also presented in a study conducted by Ekonomou and Kallioras (2020).

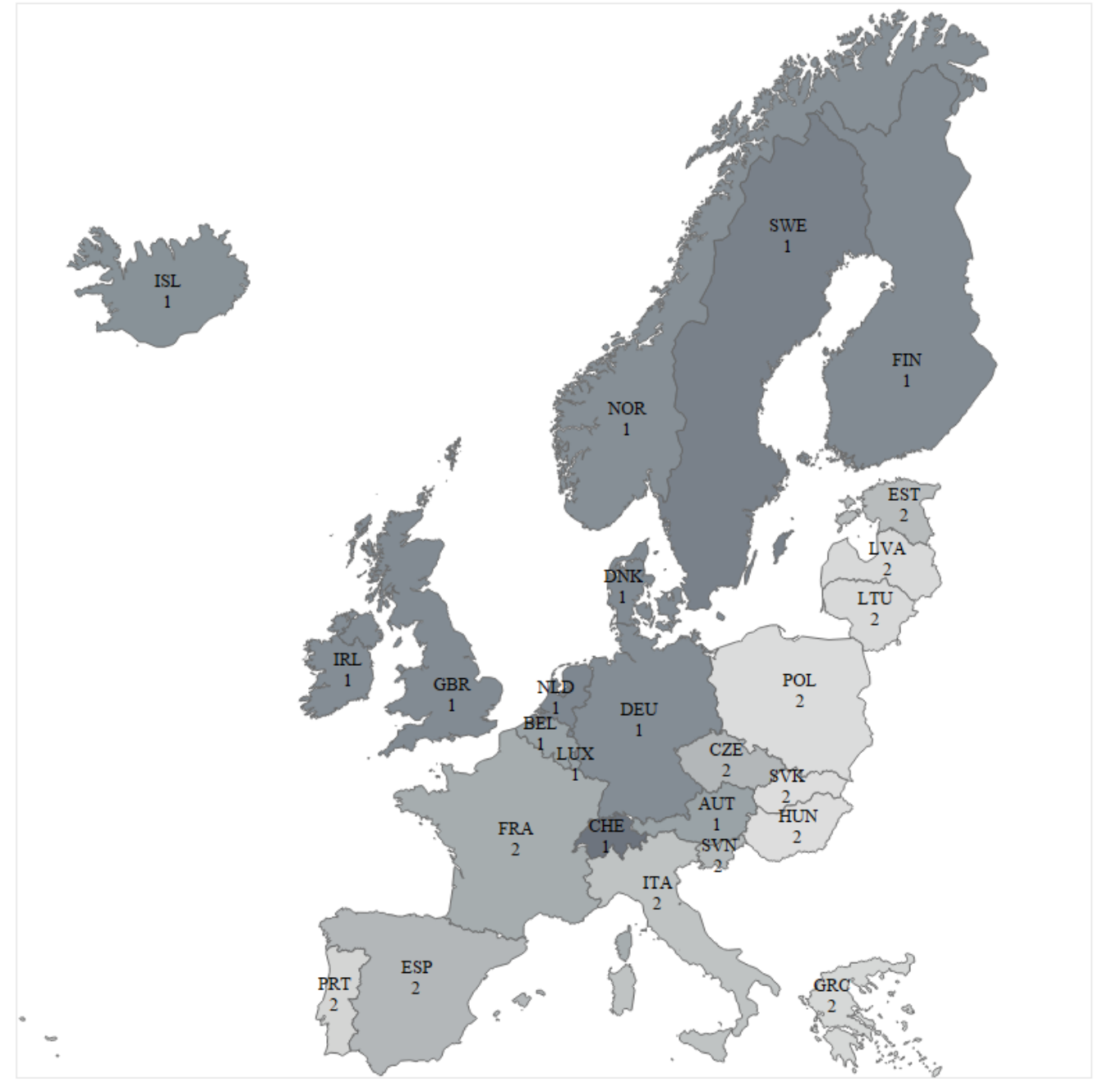

Figure 2. Clusters in a geographical context

Source: own elaboration 
ENTREPRENEURSHIP AND SUSTAINABILITY ISSUES

ISSN 2345-0282 (online) http://jssidoi.org/jesi/ 2021 Volume 9 Number 2 (December)

http://doi.org/10.9770/jesi.2021.9.2(35)

Figure 2 shows the examined countries in a geographical context, and the intensity of their shadow indicates their development. In other words, the more intense shadow presents a higher value of the standardized average GII and HDI indicators (the more intense the shadow, the higher the level of development). The number assigned to the countries indicates the cluster in which they were included.

Table 1. Descriptive analysis of road transport indicators and tourism spending indicators

\begin{tabular}{|c|c|c|c|c|c|c|c|c|c|c|c|c|c|c|c|}
\hline \multirow{2}{*}{ ID } & \multirow{2}{*}{$\begin{array}{l}\text { C } \\
\text { I }\end{array}$} & \multicolumn{2}{|c|}{ DENSITY } & \multicolumn{2}{|c|}{ URBAN } & \multicolumn{2}{|c|}{ INVEST } & \multicolumn{2}{|c|}{ BTS } & \multicolumn{2}{|c|}{ LTS } & \multicolumn{2}{|c|}{ DTS } & \multicolumn{2}{|c|}{ VEFS } \\
\hline & & Mean & Med & Mean & Med & Mean & Med & Mean & Med & Mean & Med & Mean & Med & Mean & Med \\
\hline AUT & 1 & 155.16 & 150.97 & 71.82 & 71.24 & 0.12 & 0.12 & 576.9 & 574.6 & 3480.2 & 3474.2 & 2090.6 & 2093.8 & 1966.5 & 1951.3 \\
\hline BEL & 1 & 510.49 & 510.49 & - & - & 0.14 & 0.15 & 427.9 & 423.9 & 1213.9 & 1209.6 & 742.7 & 728.2 & 899.1 & 968.5 \\
\hline CHE & 1 & 180.96 & 180.99 & - & - & 0.70 & 0.69 & 511.4 & 511.5 & 2876.9 & 2870.3 & 1933.1 & 1935.8 & 1455.1 & 1445.5 \\
\hline CZE & 2 & 72.18 & 72.18 & 30.03 & 30.00 & 0.58 & 0.51 & 277.7 & 258.2 & 1176.4 & 1180.7 & 593.3 & 578.4 & 860.8 & 855.6 \\
\hline DEU & 1 & - & - & - & - & 0.44 & 0.43 & 615.6 & 607.3 & 2941.2 & 2930.2 & 3065.5 & 3031.2 & 491.3 & 496.1 \\
\hline EST & 2 & 136.64 & 136.02 & 8.55 & 8.66 & 0.90 & 0.89 & 658.5 & 681.1 & 2130.5 & 2166.6 & 714.9 & 699.5 & 2074.2 & 2145.9 \\
\hline FIN & 1 & 25.68 & 25.69 & 10.80 & 11.25 & 0.56 & 0.56 & 788.6 & 781.4 & 2047.9 & 2072.7 & 2089.1 & 2102.8 & 747.4 & 782.3 \\
\hline FRA & 2 & 196.69 & 198.01 & 14.76 & 14.82 & 0.53 & 0.50 & 490.6 & 484.6 & 2034.3 & 2020.4 & 1694.3 & 1687.9 & 830.5 & 806.1 \\
\hline GBR & 1 & 174.22 & 174.21 & 35.57 & 35.27 & 0.33 & 0.34 & 902.0 & 872.7 & 1901.4 & 1918.1 & 2309.9 & 2367.2 & 493.6 & 504.7 \\
\hline ITA & 2 & 86.40 & 86.76 & - & - & 0.24 & 0.22 & 601.2 & 579.6 & 2440.4 & 2538.5 & 2317.2 & 2400.4 & 724.3 & 735.4 \\
\hline LTU & 2 & 134.29 & 134.62 & 78.79 & 82.06 & 0.87 & 0.73 & 248.9 & 255.3 & 898.2 & 904.8 & 484.6 & 503.5 & 662.5 & 671.7 \\
\hline LUX & 1 & 124.67 & 119.30 & 25.75 & 25.75 & 0.43 & 0.44 & 183.2 & 170.2 & 3749.4 & 3850.0 & 696.6 & 694.8 & 3236.0 & 3324.7 \\
\hline LVA & 2 & 94.16 & 94.18 & 15.29 & 15.36 & 0.83 & 0.83 & 278.4 & 282.8 & 1357.8 & 1376.2 & 682.3 & 687.3 & 953.9 & 911.8 \\
\hline NLD & 1 & 412.50 & 412.32 & 52.08 & 52.08 & 0.36 & 0.36 & 426.1 & 406.6 & 1243.2 & 1240.0 & 876.5 & 869.5 & 792.8 & 777.2 \\
\hline NOR & 1 & 25.90 & 25.89 & - & - & 0.96 & 1.01 & 576.4 & 555.2 & 1769.1 & 1635.8 & 1655.0 & 1538.5 & 690.5 & 652.5 \\
\hline POL & 2 & 135.99 & 136.20 & 16.38 & 16.36 & 0.96 & 0.69 & 171.5 & 150.1 & 482.6 & 481.9 & 211.0 & 209.5 & 443.1 & 438.5 \\
\hline PRT & 2 & 15.36 & 15.62 & - & - & 0.38 & 0.16 & 522.2 & 548.1 & 2806.6 & 2811.7 & 1198.3 & 1253.2 & 2130.6 & 2085.2 \\
\hline SVK & 2 & 108.03 & 114.01 & - & - & 0.76 & 0.72 & 359.2 & 341.8 & 866.6 & 814.6 & 626.0 & 608.4 & 599.9 & 553.3 \\
\hline SVN & 2 & 100.25 & 100.17 & 31.54 & 31.20 & 0.34 & 0.29 & 387.6 & 374.3 & 2240.8 & 2240.2 & 909.3 & 906.5 & 1719.1 & 1712.9 \\
\hline
\end{tabular}

Note: ID - country identifier; Cl - cluster; Med - median; Diff Test - difference test; DENSITY - density of road km per one hundred square km; URBAN - share of urban roads in total road network; INVEST - road infrastructure investment per gross domestic product; BTS - business tourism spending; LTS - leisure tourism spending; DTS - domestic tourism spending; VEFS - foreign visitors spending; pvalue $<0.01-* * * ;$ p-value $<0.001-\dagger$

Source: own elaboration 
Table 1 shows the measures of the central tendency (mean, median) for individual countries. The table also contains a column, in which the cluster $(\mathrm{Cl})$ is defined for each country. Missing values were identified for the DENSITY and URBAN indicators in several countries. At this point, it should be noted that these countries were not included in the bivariate analytical procedures, i.e., they were excluded from the sample. At the end of the table, the rows CL 1 and CL 2 show the results for the individual identified clusters (groups) of countries. The last row contains the results of the difference test, which evaluated the differences in individual indicators between cluster 1 and cluster 2 .

Significant differences were found in most indicators. In terms of road transport indicators, significant differences were identified for DENSITY and INVEST. For DENSITY, a higher value of central tendency measures was observed in cluster 1 (mean $=169.70$; median $=150.97)$. This indicates that the countries included in cluster 1 (more developed countries) were characterized by a higher density of roads. On the contrary, for INVEST, higher values of central tendency measures were observed in cluster 2 (mean $=0.68$; median $=0.61)$. Accordingly, the countries included in cluster 2 (less developed countries) were characterized by higher investments in road infrastructure per gross domestic product.

The revealed findings can be understood as meaning that more developed countries already have a quality road infrastructure, while less developed countries are only in the process of building it. In line with this assumption, a higher level of road infrastructure in more developed countries encourages higher road density, while efforts to build better road infrastructure require more investment in less developed countries.

These efforts are mainly aimed at reducing inequalities in transport infrastructure between different countries, which can also help to address the problems of uneven economic growth across countries in the long term (Chen et al. 2021). In fact, investments in transport are a key aspect of economic growth. Countries thus have the opportunity to improve their position in the development assessment presented in this study. In addition, investments in transport and communications infrastructure have a strong and positive impact on international visitor attraction (Nguyen 2021), which may be reflected in tourism demand and, consequently, in tourism spending.

In terms of tourism spending indicators, significant differences were identified for BTS, LTS and DTS, and higher values of central tendency measures were observed in cluster 1 . This suggests that the countries included in cluster 1 reported significantly higher business tourism spending, leisure tourism spending, and domestic tourism spending. These results were expected, as more developed countries also have more developed tourism. The results in this study can be compared with the results of Szajt (2018), who took a closer look at changes in tourism spending in the countries of the European Union and economic development. 
ENTREPRENEURSHIP AND SUSTAINABILITY ISSUES

ISSN 2345-0282 (online) http://jssidoi.org/jesi/ 2021 Volume 9 Number 2 (December) http://doi.org/10.9770/jesi.2021.9.2(35)

Table 2. Correlation matrix in cluster specification - Spearman's $\rho$

\begin{tabular}{|c|c|c|c|c|c|c|c|}
\hline Indicator & DENSITY & URBAN & INVEST & BTS & LTS & DTS & VEFS \\
\hline \multicolumn{8}{|c|}{ cluster 1} \\
\hline DENSITY & & 0.767 & -0.431 & -0.280 & -0.363 & -0.185 & 0.057 \\
\hline URBAN & $<0.001$ & & -0.924 & -0.304 & 0.335 & 0.191 & 0.339 \\
\hline INVEST & $<0.001$ & $<0.001$ & & 0.008 & 0.091 & 0.068 & -0.163 \\
\hline BTS & 0.006 & 0.067 & 0.931 & & 0.198 & 0.579 & -0.045 \\
\hline LTS & $<0.001$ & 0.043 & 0.345 & 0.033 & & 0.596 & 0.475 \\
\hline DTS & 0.071 & 0.257 & 0.482 & $<0.001$ & $<0.001$ & & -0.230 \\
\hline VEFS & 0.579 & 0.040 & 0.091 & 0.629 & $<0.001$ & 0.013 & \\
\hline \multicolumn{8}{|c|}{ cluster 2} \\
\hline DENSITY & & -0.117 & 0.299 & -0.276 & -0.317 & -0.361 & -0.167 \\
\hline URBAN & 0.365 & & -0.170 & -0.534 & -0.402 & -0.382 & -0.352 \\
\hline INVEST & 0.004 & 0.186 & & -0.344 & -0.294 & -0.411 & 0.036 \\
\hline BTS & 0.006 & $<0.001$ & $<0.001$ & & 0.516 & 0.661 & 0.376 \\
\hline LTS & 0.001 & 0.001 & 0.002 & $<0.001$ & & 0.822 & 0.809 \\
\hline DTS & $<0.001$ & 0.002 & $<0.001$ & $<0.001$ & $<0.001$ & & 0.437 \\
\hline VEFS & 0.099 & 0.005 & 0.708 & $<0.001$ & $<0.001$ & $<0.001$ & \\
\hline
\end{tabular}

Source: own elaboration

Table 2 shows the results of a nonparametric correlation analysis in which the cluster specification was applied. The upper part above the diagonal of the individual matrices contains correlation coefficients and the lower part below the diagonal contains p-values expressing the statistical significance of coefficients. Negative coefficients are highlighted in red and positive coefficients are highlighted in green. Coefficients with a significance level of 0.05 and lower are highlighted in bold. A richer colour indicates a stronger correlation. Significant differences in correlations between more developed countries (cluster 1) and less developed countries (cluster 2) could be observed in a substantial number of analysed cases. Focusing on the correlations with DENSITY, different results were found for URBAN ( $\rho$ : cluster $1=0.767$; cluster $2=-0.117$ ) and INVEST ( $\rho$ : cluster $1=-0.431$; cluster $2=$ 0.299). Regarding the correlations with URBAN, different results between clusters were evident for all indicators. In terms of the correlations with INVEST, it was possible to observe different results between clusters in all indicators with one exception, which was VEFS. Interestingly, different results were also identified in terms of tourism spending indicators and their correlations. A significant and positive correlation between BTS and VEFS was revealed in cluster $2(\rho=0.376$, p-value $=<0.001)$, but this was not true in cluster 1 , where the significance of this correlation was not confirmed $(\rho=-0.045$, $p$-value $=0.629)$. The most obvious difference was found in the correlation between DTS and VEFS ( $\rho$ : cluster $1=-0.230$; cluster $2=0.437$ ). Thus, differences between clusters of countries were also revealed by correlation analysis. All these confrontational findings require further research. 
Table 3. PLM - selection of the most suitable model

\begin{tabular}{lcc}
\hline Reg. Model & PLM model & PLM model \\
& Cluster 1 & Cluster 2 \\
\hline DENSITY $\rightarrow$ BTS & RND & WTN \\
DENSITY $\rightarrow$ LTS & RND & WTN \\
DENSITY $\rightarrow$ DTS & RND & RND \\
DENSITY $\rightarrow$ VEFS & RND & WTN \\
URBAN $\rightarrow$ BTS & RND & RND \\
URBAN $\rightarrow$ LTS & RND & RND \\
URBAN $\rightarrow$ DTS & RND & RND \\
URBAN $\rightarrow$ VEFS & RND & RND \\
INVEST $\rightarrow$ BTS & RND & WTN \\
INVEST $\rightarrow$ LTS & RND & WTN \\
INVEST $\rightarrow$ DTS & RND & RND \\
INVEST $\rightarrow$ VEFS & RND & RND \\
\hline Note: RND - White 2 Random ind ID; WTN - Arellano Within ind ID &
\end{tabular}

Source: own elaboration

Table 3 specifies the most suitable methods for estimates in the applied regression analyses. These concretisations of the methods were selected on the basis of several tests ( $F$ test for individual and time effects, Hausman test), the results of which are given in Appendix 1.

Table 4. Results of PLM regression models

\begin{tabular}{|c|c|c|c|}
\hline Model & Coef & $\begin{array}{l}\text { PLS model } \\
\text { Cluster } 1\end{array}$ & $\begin{array}{l}\text { PLS model } \\
\text { Cluster } 2\end{array}$ \\
\hline \multirow{2}{*}{$\mathrm{DENSITY} \rightarrow \mathrm{BTS}$} & $\bar{\beta}$ & -0.580 & \multirow{2}{*}{$2.06 * * *$} \\
\hline & $\mathrm{a}$ & 726.360 & \\
\hline \multirow{2}{*}{ DENSITY $\rightarrow$ LTS } & $\beta$ & -0.80 & \multirow{2}{*}{$10.90 * *$} \\
\hline & $\mathrm{a}$ & $2,236.640$ & \\
\hline \multirow{2}{*}{ DENSITY $\rightarrow$ DTS } & $\beta$ & -1.350 & 1.190 \\
\hline & $\mathrm{a}$ & $1,688.970$ & 747.280 \\
\hline \multirow{2}{*}{ DENSITY $\rightarrow$ VEFS } & $\beta$ & 0.080 & \multirow{2}{*}{$10.13 * *$} \\
\hline & $\mathrm{a}$ & $1,255.060$ & \\
\hline \multirow{2}{*}{$\mathrm{URBAN} \rightarrow \mathrm{BTS}$} & $\beta$ & -2.510 & -0.380 \\
\hline & $\mathrm{a}$ & 705.020 & 337.970 \\
\hline \multirow{2}{*}{$\mathrm{URBAN} \rightarrow \mathrm{LTS}$} & $\beta$ & 6.480 & -1.250 \\
\hline & $\mathrm{a}$ & $2,164.720$ & $1,484.470$ \\
\hline \multirow{2}{*}{$\mathrm{URBAN} \rightarrow \mathrm{DTS}$} & $\beta$ & 1.990 & 4.60 \\
\hline & $\mathrm{a}$ & $1,571.070$ & 583.790 \\
\hline \multirow{2}{*}{$\mathrm{URBAN} \rightarrow \mathrm{VEFS}$} & $\beta$ & 2.740 & -3.580 \\
\hline & $\mathrm{a}$ & $1,269.680$ & $1,163.770$ \\
\hline \multirow{2}{*}{$\mathrm{INVEST} \rightarrow \mathrm{BTS}$} & $\beta$ & -67.380 & \multirow{2}{*}{-16.18} \\
\hline & $\mathrm{a}$ & 735.470 & \\
\hline \multirow{2}{*}{$\mathrm{INVEST} \rightarrow \mathrm{LTS}$} & $\beta$ & -298.990 & \multirow{2}{*}{152.8} \\
\hline & $\mathrm{a}$ & $2,655.630$ & \\
\hline \multirow{2}{*}{$\mathrm{INVEST} \rightarrow \mathrm{DTS}$} & $\beta$ & 177.850 & -5.460 \\
\hline & $\mathrm{a}$ & $1,604.580$ & 965.810 \\
\hline \multirow{2}{*}{ INVEST $\rightarrow$ VEFS } & $\beta$ & -576.770 & 134.180 \\
\hline & $\mathrm{a}$ & $1,799.340$ & $1,088.380$ \\
\hline
\end{tabular}

Source: own elaboration 


\section{ENTREPRENEURSHIP AND SUSTAINABILITY ISSUES}

ISSN 2345-0282 (online) http://jssidoi.org/jesi/ 2021 Volume 9 Number 2 (December) http://doi.org/10.9770/jesi.2021.9.2(35)

Table 4 shows the results of regression models, based on which it was possible to confirm a positive and significant association in only three analysed cases, namely between DENSITY and BTS $\left(\beta=2.06^{* * *}\right)$, between DENSITY and LTS $\left(\beta=10.9^{* *}\right)$, and between DENSITY and VEFS $\left(\beta=10.13^{* *}\right)$. These associations were found in cluster 2 , i.e., in less developed countries. The findings revealed the fact that in less developed countries, a higher density of roads can be reflected in higher business tourism spending, leisure tourism spending, and foreign visitors spending. The findings of this study may follow the findings of Zhang J. and Zhang Y. (2021), who revealed a significant association between transport infrastructure (represented by highways) and tourism. More specifically, Zhang et al. (2021) also revealed the effect of road network density on tourism. This study did not confirm any significant association between road infrastructure investment and foreign visitors' spending, while the findings of Nguyen (2021) indicated a strong and positive impact of transport investments on foreign visitor attraction. On this basis, it was assumed that a higher foreign visitor attraction would be reflected in their willingness to pay, as well as in tourism spending as such. However, this was not supported in the presented study. This can be explained by the fact that the study covered only investments in road infrastructure, while the inclusion of investments in all types of transport infrastructure could show different results. The nature of participation in tourism in terms of length of stay should also be considered, Michniak et al. (2014) revealed that investments in road infrastructure may lead to an intensification of weekend-tourism or several days' tourism, indicating expected higher tourism spending. On the other hand, the authors pointed out a minor effect of the investments in terms of the choice of long-term stays. Further research is needed in this regard. Also, the fact remains that tourism is a very complex research area, and many other factors should be taken into account (Feriyanto et al. 2019, Kozicka et al. 2019).

\section{Conclusions}

The research objective of this study was to assess the links between selected indicators of road transport and tourism spending using bivariate analysis of effects. The study applied a development approach in European OECD countries. The applied cluster analysis divided the examined countries into two homogenous clusters based on the Human Development Index and the Global Innovation Index. Accordingly, more developed countries (cluster 1) and less developed countries (cluster 2) were included into the main analyses. Descriptive analysis provided a first look at the data. It was the difference analysis that revealed significant differences in road transport indicators and tourism spending indicators between cluster 1 and cluster 2 . In general, more developed countries were characterized by a significantly higher density of roads. On the other hand, less developed countries were characterized by significantly higher investments in road infrastructure per gross domestic product. In terms of tourism spending indicators, more developed countries reported significantly higher business tourism spending, leisure tourism spending, and domestic tourism spending. The results of the correlation analysis also revealed considerable differences in the significance and direction of correlations between countries with a higher level of development and countries with a lower level of development. It could be stated very cautiously that, in terms of the correlations between road transport indicators and tourism visitors' spending, positive coefficients prevailed in countries with a higher level of development, and negative coefficients prevailed in countries with a lower level of development. Using panel regression models, it was possible to confirm significant associations between road transport indicators and tourism spending in only three analysed cases. In all three cases, these findings were observed in countries with a lower level of development and in the road density indicator. On the basis of a positive trajectory, it could be concluded that an increase in road density can be associated with an increase in tourism spending (business, leisure and foreign) in less developed countries.

Focusing on policy implications and recommendations, this study offers a valuable platform of important findings needed for evidence-based decision-making at national and international levels. The results could be of interest to strategic planners and policy makers, who should know the situation from every perspective in order to strengthen tourism and infrastructure and thus the economy. Deeper knowledge can ensure effective decisions. 


\section{ENTREPRENEURSHIP AND SUSTAINABILITY ISSUES}

ISSN 2345-0282 (online) http://jssidoi.org/jesi/ 2021 Volume 9 Number 2 (December)

http://doi.org/10.9770/jesi.2021.9.2(35)

The study provides new knowledge in the issue of tourism and transport infrastructure, while a specific research optic has been applied. It has been shown that in less developed countries, progress in the development of road infrastructure could be associated with increased tourism spending, and this should be taken into account by decision-makers in these countries. The results indicated that the development of countries played an important role in evaluating the links examined in this study. In countries with a lower or higher level of development, various ways should be sought to improve economic prosperity as well as sustainability. The links between the indicators of road transport and tourism spending have not been sufficiently examined; therefore, it can be stated that the study filled this research gap and brought novelty and a new perspective on the issue.

Potential limitations can also be identified in this study. For instance, the findings can be generalized only to OECD countries. Future research activities will focus on other indicators of transport infrastructure, as well as other indicators expressing the development of tourism, which would be closer to each other in practical life.

\section{References}

Albaladejo, I. P., González-Martínez, M. I., \& Martínez-García, M. P. (2014). Quality and endogenous tourism: An empirical approach. Tourism Management, 41, 141-147. http://dx.doi.org/10.1016/j.tourman.2013.09.006

Belas, J., Amoah, J., Petráková, Z., Kliuchnikava, Y., \& Bilan, Y. (2020a). Selected factors of SMEs management in the service sector. Journal of Tourism and Services, 21(11), 129-146. http://dx.doi.org/10.29036/jots.v11i21.215

Belas, J., Gavurova, B., Cepel, M., \& Kubak, M. (2020b). Evaluation of economic potential of business environment development by comparing sector differences: Perspective of SMEs in the Czech Republic and Slovakia. Oeconomia Copernicana, 11(1), 135-159. http://dx.doi.org/10.24136/oc.2020.006

Belas, J., Gavurova, B., \& Toth, P. (2018). Impact of selected characteristics of SMEs on the capital structure. Journal of Business Economics and Management, 19(4), 592-608. http://dx.doi.org/10.3846/jbem.2018.6583

Brida, J. G., \& Scuderi, R. (2013). Determinants of tourist expenditure: A review of microeconometric models. Tourism Management Perspectives, 6, 28-40. http://dx.doi.org/10.1016/j.tmp.2012.10.006

Chen, A., Li, Y., Ye, K., Nie, T., \& Liu, R. (2021). Does transport infrastructure inequality matter for economic growth? Evidence from China. Land, 10(8), 874. http://dx.doi.org/10.3390/land10080874

Civelek, M., Gajdka, K., Světlík, J., \& Vavrečka, V. (2020). Differences in the usage of online marketing and social media tools: Evidence from Czech, Slovakian and Hungarian SMEs. Equilibrium. Quarterly Journal of Economics and Economic Policy, 15(3), 537-563. http://dx.doi.org/10.24136/eq.2020.024

Civelek, M., Ključnikov, A., Fialova, V., Folvarčná, A., \& Stoch, M. (2021). How innovativeness of family-owned SMEs differ depending on their characteristics? Equilibrium. Quarterly Journal of Economics and Economic Policy, 16(2), 413-428. http://dx.doi.org/10.24136/eq.2021.015

Cornell University, INSEAD and WIPO. (2021). About the Global Innovation Index. Retrieved November 4, 2021 from https://www.globa-linnovationindex.org/about-gii\#reports

Costea, M., Hapenciuc, C. V., \& Arionesei, G. (2017). The general transport infrastructure - a key determinant of competitiveness of tourism in Romania and CEE-EU countries. In P. Hajek, O. Vit, P. Basova, M. Krijt, H. Paszekova, O. Souckova, \& R. Mudrik (Eds.), CBU International Conference Proceedings 2017: Innovations in Science and Education, Vol. 5 (pp. 79-85). http://dx.doi.org/10.12955/cbup.v5.906

David-Negre, T., Hernandez, J. M., \& Moreno-Gil, S. (2018). Understanding tourists' leisure expenditure at the destination: A social network analysis. Journal of Travel \& Tourism Marketing, 35(7), 922-937. http://dx.doi.org/10.1080/10548408.2018.1447533

Dogru, T., \& Bulut, U. (2018). Is tourism an engine for economic recovery? Theory and empirical evidence. Tourism Management, 67, 425-434. http://dx.doi.org/10.1016/j.tourman.2017.06.014 


\section{ENTREPRENEURSHIP AND SUSTAINABILITY ISSUES}

ISSN 2345-0282 (online) http://jssidoi.org/jesi/ 2021 Volume 9 Number 2 (December)

http://doi.org/10.9770/jesi.2021.9.2(35)

Dragicevic, V., Jovicic, D., Blesic, I., Stankov, U., \& Boskovic, D. (2012). Business tourism destination competitiveness: A case of Vojvodina province (Serbia). Economic Research-Ekonomska Istraživanja, 25(2), 311-331. $\underline{\text { http://dx.doi.org/10.1080/1331677X.2012.11517510 }}$

Ekonomou, G. \& Kallioras, D. (2020). Business tourism spending in Eurozone countries: Detecting for convergence trends. European Journal of Tourism Research, 26, 2610. Retrieved November 4, 2021 from https://ejtr.vumk.eu/index.php/about/article/view/1941

Feriyanto, N., Kot, S., Sugandini, D., \& Muafi. (2019). The development of community based tourism: From attractiveness to loyalty. Quality-Access to Success, 20(S1), 393-398.

Fredman, P. (2008). Determinants of visitor expenditures in mountain tourism. Tourism Economics, 14(2), 297-311. http://dx.doi.org/10.5367/000000008784460418

Garcia-Sanchez, A., Fernandez-Rubio, E., \& Collado, M. D. (2013). Daily expenses of foreign tourists, length of stay and activities: Evidence from Spain. Tourism Economics, 19(3), 613-630. http://dx.doi.org/10.5367/te.2013.0218

Gavurova, B., Ivankova, V., Rigelsky, M., \& Přívarová, M. (2020). Relations between tourism spending and global competitiveness - an empirical study in developed OECD Countries. Journal of Tourism and Services, 21(11), 38-54. http://dx.doi.org/10.29036/jots.v11i21.175

Haller, A. P., Butnaru, G. I., Harsan, G. D. T., \& Stefanica, M. (2020). The relationship between tourism and economic growth in the EU28. Is there a tendency towards convergence? Economic Research-Ekonomska Istrazivanja, 34(1), 1121-1145. http://dx.doi.org/10.1080/1331677X.2020.1819852

Human Development Reports. (2021). United Nations Development Programme. Retrieved November 4, 2021 from http://hdr.undp.org/en

Horak J., Suler P., \& Vrbka J. (2020). Analysis of transportation companies in the Czech Republic by the Kohonen networks identification of industry leaders. Communications - Scientific Letters of the University of Zilina, 23(1), 32-43. http://dx.doi.org/10.26552/COM.C.2021.1.A32-A43

Jou, R. C., Hensher, D., \& Su, W. C. (2012). The influence of new road infrastructure on tourism behaviour in Taiwan: The Sun Moon Lake experience. Road \& Transport Research, $21 \quad$ (4), 50-61. Retrieved November 4, 2021 from https://search.informit.org/doi/10.3316/informit.145544694512676

Kanwal, S., Rasheed, M.I., Pitafi, A.H., Pitafi, A., \& Ren, M. (2020). Road and transport infrastructure development and community support for tourism: The role of perceived benefits, and community satisfaction. Tourism Management, 77, 104014. http://dx.doi.org/10.1016/j.tourman.2019.104014

Kassambara, A. (2017). Practical guide to cluster analysis in R: Unsupervised machine learning (Volume 1). Paris: STHDA.

Khadaroo, J., \& Seetanah, B. (2007). Transport infrastructure and tourism development. Annals of Tourism Research, 34(4), 1021-1032. http://dx.doi.org/10.1016/j.annals.2007.05.010

Khadaroo, J., \& Seetanah, B. (2008). The role of transport infrastructure in international tourism development: A gravity model approach. Tourism Management, 29(5), 831-840. http://dx.doi.org/10.1016/j.tourman.2007.09.005

Ključnikov, A., Civelek, M., Fialova, V., \& Folvarčná, A. (2021). Organizational, local, and global innovativeness of family-owned SMEs depending on firm-individual level characteristics: evidence from the Czech Republic. Equilibrium. Quarterly Journal of Economics and Economic Policy, 16(1), 169-184. http://dx.doi.org/10.24136/eq.2021.006

Ključnikov, A., Civelek, M., Polách, J., Mikoláš, Z., \& Banot, M. (2020a). How do security and benefits instill trustworthiness of a digital local currency? Oeconomia Copernicana, 11(3), 433-465. http://dx.doi.org/10.24136/oc.2020.018

Ključnikov, A., Civelek, M., Vozňáková, I., \& Krajčík, V. (2020b). Can discounts expand local and digital currency awareness of individuals depending on their characteristics? Oeconomia Copernicana, 11(2), 239-266. http://dx.doi.org/10.24136/oc.2020.010

Kozicka, K., Kot, S., \& Riana, I. G. (2019). The efficiency of cooperation between the participants in the supply chain in the tourismrelated branch of industry in relation to client satisfaction. Sustainability, 11(17), 4716. http://dx.doi.org/10.3390/su11174716 


\section{ENTREPRENEURSHIP AND SUSTAINABILITY ISSUES}

ISSN 2345-0282 (online) http://jssidoi.org/jesi/ 2021 Volume 9 Number 2 (December)

http://doi.org/10.9770/jesi.2021.9.2(35)

Lăzăroiu G., Machova V., \& Kucera J. (2020). Connected and autonomous vehicle mobility: Socially disruptive technologies, networked transport systems, and big data algorithmic analytics. Contemporary Readings in Law and Social Justice, 12(2), 61-69. http://dx.doi.org/10.22381/CRLSJ12220207

Li, J., Zhang, W., Xu, H., \& Jiang, J. (2015). Dynamic competition and cooperation of road infrastructure investment of multiple tourism destinations: A case study of Xidi and Hongcun World Cultural Heritage. Discrete Dynamics in Nature and Society, $2015,962028$. $\underline{\text { http://dx.doi.org/10.1155/2015/962028 }}$

Liska, M. (2016). Travelling by train between Czechoslovakia and Germany after the Munich agreement. Littera Scripta, 9(3), 24-31.

Majerova, J., \& Fernandes, C. (2020). How to make phoenix to arise from the ashes: Brand loyalty as a prospective pillar of branding in tourism after crisis COVID-19. Littera Scripta, 13(2), 49-58. http://dx.doi.org/10.36708/Littera Scripta2020/2/5

Mamirkulova, G., Mi, J., Abbas, J., Mahmood, S., Mubeen, R., \& Ziapour, A. (2020). New Silk Road infrastructure opportunities in developing tourism environment for residents better quality of life. Global Ecology and Conservation, $24, \mathrm{e} 01194$. http://dx.doi.org/10.1016/j.gecco.2020.e01194

Michniak, D., Wieckowski, M., Komornicki, T., Rosik, P., Stepniak, M., \& Sleszynski, P. (2014). Analysis of the impact of investment to road infrastructure on tourism development in the Polish-Slovak borderland. Ekonomicky Casopis, 62(5), 540-554.

Nenavath, S. (2021). Does transportation infrastructure impact economic growth in India? Journal of Facilities Management. http://dx.doi.org/10.1108/JFM-03-2021-0032

Nguyen, Q. H. (2021). Impact of investment in tourism infrastructure development on attracting international visitors: A nonlinear panel ARDL approach using Vietnam's data. Economies, 9(3), 131. http://dx.doi.org/10.3390/economies9030131

Nicula, V., \& Elena, P. R. (2014). Business tourism market developments. Procedia Economics and Finance, 16, 703-712. http://dx.doi.org/10.1016/S2212-5671(14)00858-2

OECD. (2021). OECD.Stat. Retrieved November 4, 2021 from https://stats.oecd.org

Pradhan, R. P., Arvin, M. B., \& Nair, M. (2021). Urbanization, transportation infrastructure, ICT, and economic growth: A temporal causal analysis. Cities, 115, 103213. http://dx.doi.org/10.1016/j.cities.2021.103213

R Core Team. (2021). R: A language and environment for statistical computing. Vienna: R Foundation for Statistical Computing. Retrieved November 4, 2021 from https://www.R-project.org

Stehel V., \& Vochozka M. (2016). The analysis of the economical value added in transport. Nase More, 63(3), $185-188$.

Szajt, M. (2018). Changes in expenditure on tourism in European Union countries and economic development. In M. Stanickova, L. Melecky, E. Kovarova, \& K. Dvorokova (Eds.), International Conference on European Integration (pp. 1428-1435).

Uslu, A., Alagöz, G., \& Güneş, E. (2020). Socio-cultural, economic, and environmental effects of tourism from the point of view of the local community. Journal of Tourism and Services, 21(11), 1-21. http://dx.doi.org/10.29036/jots.v11i21.147

Usmani, G., Akram, V., \& Praveen, B. (2021). Tourist arrivals, international tourist expenditure, and economic growth in BRIC countries. Journal of Public Affairs, 21(2), e2202. http://dx.doi.org/10.1002/pa.2202

Uyen, J. G. (2019). SEM analysis for tourist expenditure in an emerging country. Economía y Sociedad, 24(56), 68-81. http://dx.doi.org/10.15359/eys.24-56.4

Venkatesh, U. (2006). Leisure: meaning and impact on leisure travel behaviour. Journal of Services Research, 6, 87-108.

Vochozka M., \& Machova V. (2018). Determination of value drivers for transport companies in the Czech Republic. Nase More, 65(4), 197-201. http://dx.doi.org/10.17818/NM/2018/4SI.6

Vochozka M., Rowland Z., \& Vrbka J. (2016). Financial analysis of an average transport company in the Czech Republic. Nase More, 63(3), 227-236. https://doi.org/10.17818/NM/2016/SI28 


\section{ENTREPRENEURSHIP AND SUSTAINABILITY ISSUES}

ISSN 2345-0282 (online) http://jssidoi.org/jesi/ 2021 Volume 9 Number 2 (December)

http://doi.org/10.9770/jesi.2021.9.2(35)

Vochozka M., \& Sheng P. (2016). The application of artificial neural networks on the prediction of the future financial development of transport companies. Communications: Scientific Letters of the University of Žilina, 18(2), 62-67.

Wang, Y., \& Davidson, M. C. G. (2010). A review of micro-analyses of tourist expenditure. Current Issues in Tourism, 13(6), 507-524. http://dx.doi.org/10.1080/13683500903406359

Wendt, J. A., Grama, V., Ilieş, G., Mikhaylov, A. S., Borza, S. G., Herman, G. V., \& Bógdał-Brzezińska, A. (2021). Transport infrastructure and political factors as determinants of tourism development in the cross-border region of Bihor and Maramureş. A comparative analysis. Sustainability, 13(10), 5385. http://dx.doi.org/10.3390/su13105385

Wooldridge, J. M. (2010). Econometric analysis of cross-section and panel data. London: The MIT Press.

WTTC. (2020). Total contribution to GDP. Tourism expenditure. Retrieved November 4, 2021 from https://wttc.org/

Wu, L., Zhang, J., \& Fujiwara, A. (2013). Tourism participation and expenditure behaviour: Analysis using a scobit based discretecontinuous choice model. Annals of Tourism Research, 40, 1-17. http://dx.doi.org/10.1016/j.annals.2012.09.002

Yang, C. W., Wu, C. L., \& Lu, J. L. (2021). Exploring the interdependency and determinants of tourism participation, expenditure, and duration: An analysis of Taiwanese citizens traveling abroad. Tourism Economics, 27(4), 649-669. http://dx.doi.org/10.1177/1354816619896656

Zhang, X., Song, C., Wang, C., Yang, Y., Ren, Z., Xie, M., Tang, Z., \& Tang, H. (2021). Socioeconomic and environmental impacts on regional tourism across Chinese cities: A spatiotemporal heterogeneous perspective. ISPRS International Journal of Geo-Information, 10(6), 410. chttp://dx.doi.org/10.3390/ijgi10060410

Zhang, J., \& Zhang, Y. (2021). Tourism, transport infrastructure and income inequality: A panel data analysis of China. Current Issues in Tourism. http://dx.doi.org/10.1080/13683500.2021.1928012

\section{Acknowledgements}

This paper is one of the partial outputs under the scientific research grant VEGA 1/0694/20 - Relational marketing research - perception of e-commerce aspects and its impact on purchasing behaviour and consumer preferences and VEGA 1/0609/19 - Research on the development of electronic and mobile commerce in the aspect of the impact of modern technologies and mobile communication platforms on consumer behaviour and consumer preferences. This research was supported by the Scientific Grant Agency of the Ministry of Education, Science, Research, and Sport of the Slovak Republic and the Slovak Academy Sciences as part of the research project VEGA 1/0797/20: Quantification of Environmental Burden Impacts of the Slovak Regions on Health, Social and Economic System of the Slovak Republic. 
ENTREPRENEURSHIP AND SUSTAINABILITY ISSUES

ISSN 2345-0282 (online) http://jssidoi.org/jesi/ 2021 Volume 9 Number 2 (December)

http://doi.org/10.9770/jesi.2021.9.2(35)

\section{Appendix 1}

Table 5. PLS models - assumptions

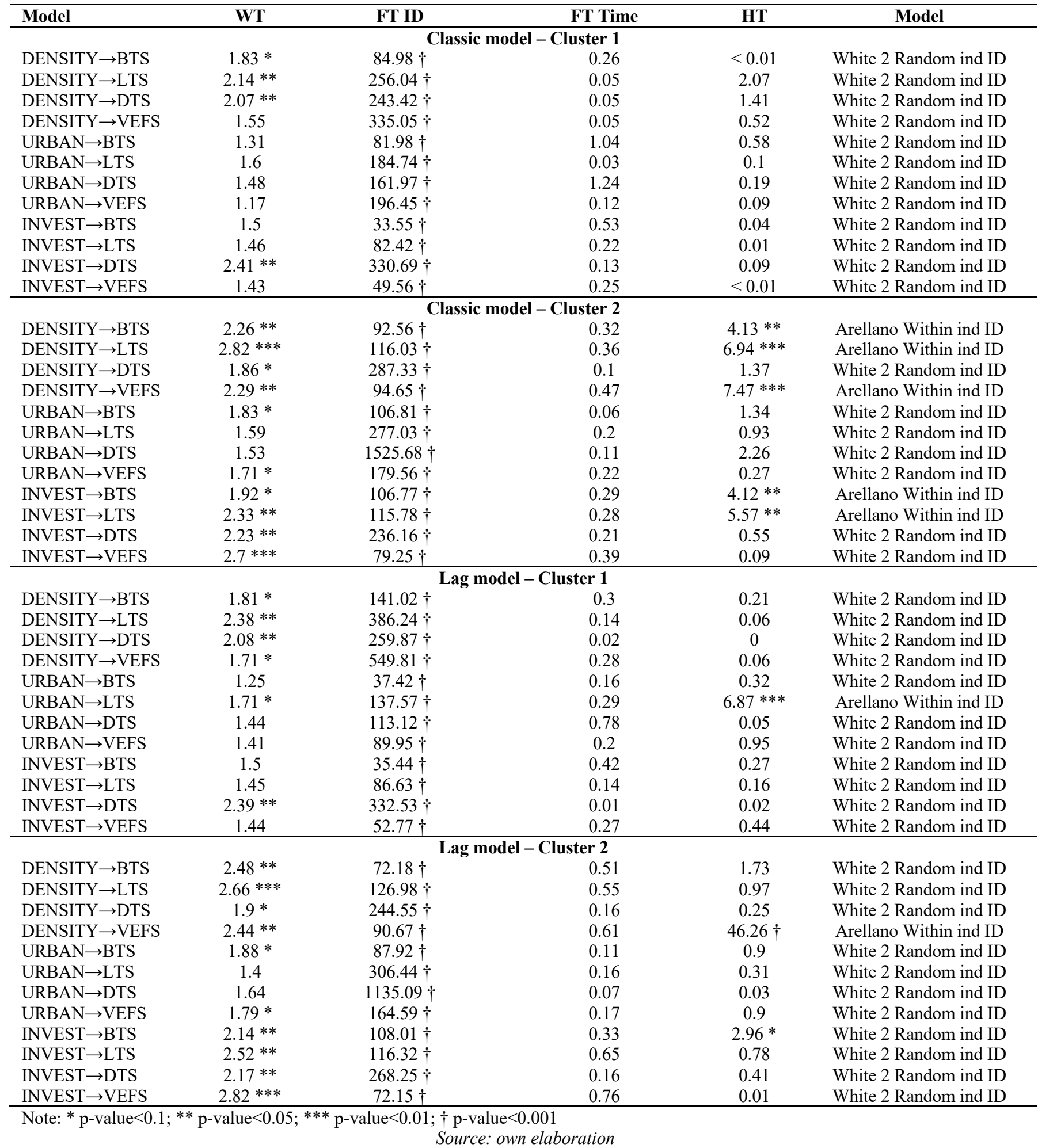




\section{ENTREPRENEURSHIP AND SUSTAINABILITY ISSUES}

ISSN 2345-0282 (online) http://jssidoi.org/jesi/

2021 Volume 9 Number 2 (December)

http://doi.org/10.9770/jesi.2021.9.2(35)

Mgr. Viera IVANKOVA, PhD., MBA currently works at the Institute of Earth Resources at the Faculty of Mining, Ecology, Process Control and Geotechnologies of the Technical University in Košice. Her dominant areas of expertise are macroeconomics and microeconomics. In her scientific and research activities, she focuses mainly on tourism, public health and environmental aspects in the economic dimension. ORCID ID: https://orcid.org/0000-0002-6164-1165

Prof. Beata GAVUROVA, PhD., MBA is an expert in finance, financial analysis and financial risk management. She focuses in her research work on issues of measurement and performance management in various sectors, process management and process optimization, strategic and performance benchmarking. Her dominant research area is the development and testing in the management and performance measurement, the evaluation of methodologies and the preparation of an application platform for innovative management and performance measurement with the support of ICT. She led several national projects, has participated in many international projects targeting the innovative applications of ICT in the private and public sector.

ORCID ID: https://orcid.org/0000-0002-0606-879X

Assoc. Prof. Radovan BACIK, PhD. has been working as a lecturer at the Department of Marketing and International Trade of the University of Prešov since 2009. In his research activities he is focusing on the issues of Public relations, Public relations in tourism, marketing of selected areas, strategic marketing, presentation of management and marketing, communication in management, branding and innovation and online marketing.

ORCID ID: $\underline{\text { https://orcid.org/0000-0002-5780-3838 }}$

Mgr. Martin RIGELSKY, PhD. currently works at the Department of Marketing and International Trade at the Faculty of Management of the University of Prešov. His scientific activities include, in particular, research in the field of economics with a focus on public health and tourism. He deals secondarily with marketing and customer behaviour.

ORCID ID: $\underline{\text { https://orcid.org/0000-0003-1427-4689 }}$

Make your research more visible, join the Twitter account of ENTREPRENEURSHIP AND SUSTAINABILITY ISSUES: (a) Entrepr69728810

Copyright (C) 2021 by author(s) and VsI Entrepreneurship and Sustainability Center

This work is licensed under the Creative Commons Attribution International License (CC BY).

http://creativecommons.org/licenses/by/4.0/

(c) (i) Open Access 